\title{
The role of surface vertical mixing in phytoplankton distribution in a stratified reservoir
}

\author{
T. Serra, ${ }^{1}$ J. Vidal, X. Casamitjana, M. Soler, and J. Colomer \\ Institut de Medi Ambient, University of Girona, Campus Montilivi, 17071-Girona, Spain
}

\begin{abstract}
We investigated convection caused by surface cooling and mixing attributable to wind shear stress and their roles as agents for the transport of phytoplankton cells in the water column by carrying out two daily surveys during the stratified period of the Sau reservoir. Green algae, diatoms, and cryptophyceae were the dominant phytoplankton communities during the surveys carried out in the middle (July) and end (September) of the stratified period. We show that a system with a linear stratification and that is subject to weak surface forcing, with weak winds $<4 \mathrm{~m} \mathrm{~s}^{-1}$ and low energy dissipation rate values of the order of $10^{-8} \mathrm{~m}^{2} \mathrm{~s}^{-3}$ or lower, enables the formation of thin phytoplankton layers. These layers quickly disappear when water parcels mix because there is a medium external forcing (convection) induced by the night surface cooling, which is characterized by energy dissipation rates on the order of $\sim 5 \times 10^{-8} \mathrm{~m}^{2} \mathrm{~s}^{-3}$. During both surveys the wind generated internal waves during the entire diurnal cycle. During the day, and because of the weak winds, phytoplankton layers rise in the water column up to a depth determined by both solar heating and internal waves. In contrast, during the night phytoplankton mixes down to a depth determined by both convection and internal waves. These internal waves, together with the wind-driven current generated at the surface, seem to be the agents responsible for the horizontal transport of phytoplankton across the reservoir.
\end{abstract}

Determining the ecological consequences of a physical structure change in the water column of an aquatic system caused by different forces acting on spatial or temporal scales, such as wind stress, cooling and heating rates, or seiching, is a challenge for controlling ecosystem productivity. Transport processes like advection and vertical convective mixing determine the paths of suspended particles in aquatic ecosystems such as lakes, reservoirs, coastal areas, and oceans (MacIntyre et al. 2002; Serra et al. 2003). Convection is a source of vertical mixing that governs the dynamics of suspended material, and advection is usually the most important mechanism for the horizontal transport of particles. In lakes and reservoirs, advection could be caused by wind-driven currents and internal waves or seiches. Hedger et al. (2004) describe the effect of advection on the spatial distribution of two phytoplankton populations, a population of dinoflagellates (Ceratium hirundinella) and a population of cyanobacteria (Microcystis spp.). They find differences between the two populations that also depend on their light irradiance requirements.

Experimental work was done with the aim of determining the effects of external forcing events on phytoplankton diversity (Rojo and Alvarez-Cobelas

${ }^{1}$ Corresponding author (teresa.serra@udg.es).

\section{Acknowledgments}

We thank the Catalan Water Agency, Aigües Ter-Llobregat, for its support throughout the campaign. We would also like to thank Joan Armengol for his unconditional support. We also thank the Servei Meteorologic de Catalunya for providing the meteorological data for the field campaign. We are also grateful to the technicians from bbe Moldaenke, who helped us to understand the methodology of the in situ fluorimeter used in this study. Finally, we thank the two reviewers for their comments, as these helped us to improve the quality of the manuscript.

This work was supported by the Spanish government (MEC) through the CGL2004-02027/HID project.
2001). Other studies have revealed the importance of the forcing timescales in phytoplankton dynamics (Cloern 1991). Simulation work with a phytoplankton model, PROTECH (Phytoplankton RespOnses To Environmental CHange), showed that the frequency and intensity of the forcing events are the main factors affecting the diversity in the phytoplankton community of an environmental system (Elliot et al. 2001). PROTECH has also been adapted to successfully simulate the evolution of the phytoplankton concentration in artificially destratified reservoirs (Lewis et al. 2002; Lewis et al. 2003).

The time resolution used during the study has important implications on the observed dynamics. Despite the limited time resolution of most phytoplankton studies (Harris and Trimbee 1986; Reynolds 1990), it must be taken into account that many processes occur during periods shorter than 1 week. A decade of observations in the South San Francisco Bay demonstrated that phytoplankton biomass fluctuates in a timescale of days to weeks (Cloern 1991). Recently, high-frequency sampling of surface picoplankton (with diameters $<3 \mu \mathrm{m}$ ) displayed 24-h periodicity in many biological variables (Jacquet et al. 1998). Spatial measurements are also crucial to understand the dynamics of thin phytoplankton layers, which are comprised of a large variety of organisms such as phytoplankton, zooplankton, and marine snow, as well as marine viruses and bacteria. McManus et al. (2005) demonstrate the effect of both currents and internal waves on the thin zooplankton layers in a coastal system. Dekshenieks et al. (2001) evaluated the behavior and occurrence of these layers depending on physical forces. Thin layers of phytoplankton have also been studied in coastal areas (Bjornsen and Nielsen 1991; Dekshenieks et al. 2001; Alldredge et al. 2002; McManus et al. 2003) and freshwater systems (Ibelings et al. 1991; Gentien et al. 1995; Bormans et al. 1999). MacIntyre and Melack (1995) also found the presence of thin layers of phytoplankton in 
Table 1. Measurement stations (see Fig. 1)

\begin{tabular}{cccc}
\hline \hline $\begin{array}{c}\text { Station } \\
\text { name }\end{array}$ & $\begin{array}{c}\text { Depth in July } \\
(\mathrm{m})\end{array}$ & $\begin{array}{c}\text { Depth in } \\
\text { September }(\mathrm{m})\end{array}$ & $\begin{array}{c}\text { Distance from the } \\
\text { dam }(\mathrm{km})\end{array}$ \\
\hline S1 & 41 & 48 & 200 \\
S2 & 40 & 47 & 800 \\
S3 & 38 & 45 & 1,600 \\
\hline
\end{tabular}

a shallow lake (Lake Nakuru). They attributed the presence of these thin layers to a reduced mixing efficiency or to advection of water from the shore. Therefore, based on all of the above findings, high-resolution temporal and spatial measurements are necessary to understand the daily dynamics of phytoplankton. New submersible fluorimeters have been developed and tested (Beutler et al. 2002; Gregor and Marsalek 2004) for estimating the total phytoplankton biomass by taking measurements of chlorophyll. These instruments are valuable for continuous sampling of phytoplankton species located in very thin layers. Leboulanger et al. (2002) used a submersible fluorometer for rapid monitoring of freshwater cyanobacteria (Planktothrix rubescens) blooms. They found good agreement between the results from the fluoroprobe and the spectrofluorometric results obtained from measurements of samples harvested from the water column. Only some deviations were found in the surface layer $(\sim 5 \mathrm{~m}$ depth) where fluorescence quenching because of high irradiance decreased the fluorescence yield.

In this study, the competition between convection and mixing induced by wind shear stress and their roles in the transport of phytoplankton through the water column was investigated during two different stratified periods. In addition, the role of advection attributable to the winddriven current and seiches was evaluated. The suspended particles under study are the algae communities thriving in the epilimnetic layer of the water column. We pay special attention to whether the different algae communities show different behaviors or respond equally under the same physical forcing acting on the system.

\section{Study site}

Sau is a canyon-shaped reservoir $18,225-\mathrm{km}$ long (Fig. 1) located in the central part of the river Ter, which is $200-\mathrm{km}$ long and has its source in the Pyrenees in northeast Spain. This reservoir has an elongated geometry with a lacustrine area 3,600-m long and a maximum width of $1,300 \mathrm{~m}$ (Armengol et al. 1999). Because Sau supplies water to the Barcelona and Girona metropolitan areas, it has been of interest since it was first filled in 1964. Its proximity to the Mediterranean Sea means that it is affected by the characteristic Mediterranean climatic variabilities, with severe interannual summer droughts. Rainfall usually reaches a maximum during spring and autumn. Aside from the climatic variability of Mediterranean regions, the daily wind pattern of the Sau reservoir is quite regular in the normal anticyclonic conditions usually prevalent during summer. During the morning the wind usually blows from the main body of the reservoir toward the dam, and in the

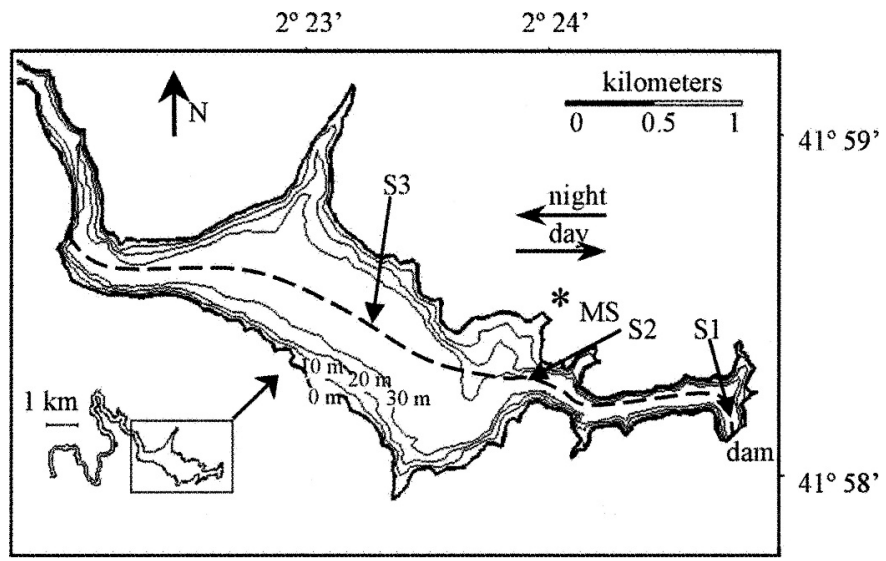

Fig. 1. Bathymetric map of the Sau reservoir with the measured stations indicated as S1, S2, and S3. The dashed line represents the main axis of the reservoir and the direction in which the wind velocity and the water currents are projected. The meteorological station (MS) was located on shore.

late afternoon and evening the wind reverses its direction and blows from the dam toward the main body of the reservoir. This wind action along the main axis of the reservoir leads us to expect the presence of seiches following this axis (Vidal et al. 2005). The stations considered for this study were S1, S2, and S3 (see Table 1 for the characteristics of these stations and Fig. 1 for their location in the reservoir).

\section{Methods}

In this study, fluorescence profiles of different phytoplankton communities were carried out using an in situ submersible five-channel fluorimeter (bbe Moldaenke) with a resolution of $0.05 \mu \mathrm{g} \mathrm{L}^{-1}$ and a measuring range of 0 $200 \mu \mathrm{g} \mathrm{L}^{-1}$. This probe determines four different communities (green algae, diatoms, cyanophyceae, and cryptophyceae), which have been previously calibrated by the manufacturer by considering particular algae populations corresponding to each algae group; for calibration specifications see Table 2. It should be taken into account that the cryptophyceae group can be contaminated by crysophyceae, which emit at a similar wavelength. In addition, the depth was measured using a pressure sensor integrated into the probe, and the temperature was measured with a sensor next to the transmission window (with a resolution of $0.01{ }^{\circ} \mathrm{C}$ and $5 \%$ accuracy). It is known that under high irradiance conditions, photosynthetic organisms regulate and protect photosynthesis by dissipating excess energy as heat. This process is the photochemical quenching that appears in shallow waters and subsurface layers (Leboulanger et al. 2002; Gregor and Marsalek 2004). This process can affect the fluorescence measurements in the upper water column down to a depth where the light level is $10 \%$ of the light at the water surface. In this situation, fluorescence values will underestimate the chlorophyll concentration values for daily profiles in the upper column. For a more detailed description of the fluoroprobe, see Beutler et al. (2002) and Gregor et al. (2005). 
Table 2. Calibration information from the manufacturer for the different phytoplankton groups that can be detected with the fluoroprobe. In the first file there is the phytoplankton population for the calibration considered for each group. The second file corresponds to the pigment that gives the fluorescence, and the last file refers to the long wave of the maximum fluorescence emitted.

\begin{tabular}{|c|c|c|c|c|}
\hline & \multicolumn{4}{|c|}{ Phytoplankton group } \\
\hline & Green algae & Cyanophyceae & Diatoms & Cryptophyceae \\
\hline $\begin{array}{l}\text { Population for } \\
\text { calibration }\end{array}$ & Chlorella vulgaris & Microcystis aeroginosa & Cyclotella meneghiniana & Cryptomonas sp. \\
\hline pigment & Chlorophyll- $a$ and $-b$ & Phycocyanin & $\begin{array}{l}\text { Xantophylls Fucoxanthin } \\
\text { Peridin }\end{array}$ & Phycoerythrin \\
\hline$\lambda(\mathrm{nm})$ & 450 & 610 & 525 & 570 \\
\hline
\end{tabular}

Measurements of current velocity profiles were carried out with an acoustic Doppler profiler (RDI $600 \mathrm{kHz}$, Workhorse Sentinel). The acoustic Doppler current profiler (ADCP) was deployed on the water surface with the beams facing downward. The ADCP was mounted on a swimming platform that was tied to the fixed buoy located in S2. As a result, we were not able to get information about the water-surface velocity (i.e. from $0-\mathrm{m}$ to $3-\mathrm{m}$ deep). Data from the ADCP were distributed in bins separated by $2 \mathrm{~m}$. The sampling rate was set at $1 \mathrm{~Hz}$ with the raw data processed to obtain 7.5-min averaged data, with a standard deviation of $0.1 \mathrm{~cm} \mathrm{~s}^{-1}$. All data were processed directly by the manufacturer software with bottom tracking to remove the ship's velocity from the measured velocity. The first depth bin was set at $3 \mathrm{~m}$, and then data from between $3 \mathrm{~m}$ and the bottom were processed. Continuous data from a moored thermistor string (Aanderaa Instruments) were also available.

Temperature values had a range resolution of $0.1 \%$ and an accuracy of $\pm 0.5^{\circ} \mathrm{C}$. The thermistor string was deployed at station S2 (see Fig. 1) and was composed of 11 thermistors placed at the following depths: $3,4,5,6,7,8$, $9,11,15,16$, and $17 \mathrm{~m}$. The sampling period of the thermistor string was $10 \mathrm{~min}$. The air temperature $\left(\mathrm{T}_{\mathrm{a}}\right.$ in ${ }^{\circ} \mathrm{C}$, with a resolution of $0.1^{\circ} \mathrm{C}$ and an accuracy of $\pm 0.3^{\circ} \mathrm{C}$ ), the relative humidity ( $\mathrm{RH}$ in \%, with a resolution of $1 \%$ and an accuracy of $\pm 3 \%$ ), the short wave radiation ( $\mathrm{q}$ in $\mathrm{Wm}^{-2}$, with a resolution of $1 \mathrm{Wm}^{-2}$ and an accuracy of $\pm 5 \mathrm{Wm}^{-2}$ ), and the wind velocity ( $\mathrm{U}$ in $\mathrm{m} \mathrm{s}^{-1}$, with a resolution of $0.1 \mathrm{~m} \mathrm{~s}^{-1}$ and an accuracy of $\pm 0.3 \mathrm{~m} \mathrm{~s}^{-1}$ ) were obtained with 1-min frequency from the meteorological station located near the dam of the reservoir. Fluorescence measurements were taken hourly during a 24-h cycle at a fixed station (S2, Fig. 1) in the Sau reservoir. This study was carried out during two different stratified conditions of the water column. The first survey was in July 2003, and the second survey was in September of the same year. In July, the field campaign began at 16:00 $\mathrm{h}$ on $23 \mathrm{Jul}$ and continued until 15:00 h on $24 \mathrm{Jul}$. In September, the field campaign went from 12:00 h on $24 \mathrm{Sep}$ to $12: 00 \mathrm{~h}$ on $25 \mathrm{Sep}$. For the survey carried out in September, fluorescence measurements at larger time intervals $(\sim 4 \mathrm{~h})$ and at other stations ( $\mathrm{S} 1$ and $\mathrm{S} 3$, see Fig. 1) were also taken. The ADCP measured velocity profiles at station S2 during the entire period in both surveys. In the September survey, another ADCP with the same technical characteristics was available and was deployed at S3 using the same procedure that was used at S2.

Estimation of penetrative velocity convection-From the meteorological values of the air temperature $\left(T_{a}\right.$, in $\left.K\right)$, the relative humidity $(\mathrm{RH})$, the wind velocity $(\mathrm{U})$, and the surface temperature of the water column $\left(\mathrm{T}_{\mathrm{w}}\right.$, in $\left.\mathrm{K}\right)$, the latent heat of evaporation (E) can be estimated following the method and equations used by Colomer et al. (1996). The sensible heat $(\mathrm{H})$ can be estimated following Imberger (1985). The net long-wave radiation, LW, can be calculated from $\mathrm{LW}=\mathrm{LW}_{\text {in }}-\mathrm{LW}_{\text {out }}$ (Kimball et al. 1982; Imberger 1985). To calculate these fluxes, the water emissivity, $\varepsilon_{\mathrm{w}}$, was set to 0.97 , and the air emissivity, $\varepsilon_{\mathrm{a}}$, was calculated from $\varepsilon_{\mathrm{a}}=0.642\left(\mathrm{e}_{\mathrm{a}} / \mathrm{T}_{\mathrm{a}}\right)^{1 / 7}$, where $\mathrm{e}_{\mathrm{a}}$ is the vapor pressure of the air, according to the formulation deduced by Brutsaert (1982). To calculate $\mathrm{LW}_{\text {in }}$, the cloud cover was estimated by visual inspection at 1 -h intervals and was found to vary between $4 / 8$ and $7 / 8$. The maximum value (7/8) was considered for estimating $\mathrm{LW}_{\text {in }}$, which represents its maximum value with a possible overestimation of $8 \%$. Therefore, the effective heat flux can be calculated by using

$\mathrm{H}^{*}=\mathrm{S}+\mathrm{q}(0)+\mathrm{q}(\mathrm{h})-(2 / \mathrm{h}) \int_{h}^{0} \mathrm{q}(\mathrm{z}) \mathrm{dz}$ (Imberger 1985).

$S$ is the net surface heat flux omitting the short-wave radiation $(\mathrm{S}=\mathrm{LW}+\mathrm{H}+\mathrm{E})$; $\mathrm{q}(\mathrm{z})$ is the short-wave radiation at a depth $\mathrm{z}$ and can be calculated from $\mathrm{q}(\mathrm{z})=$ $\mathrm{q}(0) \mathrm{e}^{-\mathrm{kz}}$, where $\mathrm{k}$ is the attenuation coefficient of light, and $\mathrm{h}$ is the depth of the mixed layer. Values of $\mathrm{k}=0.95$ and $\mathrm{k}$ $=0.7$ for the July and September surveys, respectively, were estimated from long-trend Secchi measurements in Sau reservoir (Armengol et al. 1999). From the values of $\mathrm{H}^{*}$ we can calculate the buoyancy flux B $\left(\mathrm{m}^{2} \mathrm{~s}^{-3}\right)$, defined as $\mathrm{B}=\mathrm{g} \alpha \mathrm{H}^{*} / \mathrm{C}_{\mathrm{pw}} \rho_{\mathrm{w}}$, where $\alpha$ is the thermal expansion coefficient in the range of $20^{\circ} \mathrm{C}$ to $30^{\circ} \mathrm{C}, \mathrm{C}_{\mathrm{pw}}$ is the specific heat of water, and $\rho_{\mathrm{w}}$ is the water density. The velocity scale for convective motions can be estimated by using the equation $\mathrm{w}^{*}=(\mathrm{Bh})^{1 / 3}($ Deardoff 1970).

Estimation of the surface shear velocity induced by night cooling and wind-The shear stress induced by the wind on the surface of the water column is defined as $\tau=\rho_{\mathrm{a}} \mathrm{C}_{\mathrm{D}} \mathrm{U}^{2}$, where $C_{D}$ is the drag coefficient of the water surface and can be approximated to $1.010^{-3}$, and $\rho_{\mathrm{a}}$ is the air density. Thus, the shear velocity of the layer at the surface of the water column can be calculated from $\mathrm{u}^{*}=\sqrt{\tau / \rho_{\mathrm{w}}}$. The 
combination of wind stirring and surface cooling results in a new velocity magnitude $(\eta)$ related to the mechanical energy introduced in the lake surface (Fisher et al. 1979). This velocity $\eta$ is defined as $\eta=\left(\mathrm{u}^{* 3}+v^{3} \mathrm{~W}^{* 3}\right)^{1 / 3}$, where $v=\left(\mathrm{C}_{\mathrm{k}}^{*} / \mathrm{C}_{\mathrm{k}}^{\mathrm{f}}\right)^{1 / 3}$ is defined as the ratio between the wind efficiency $\mathrm{C}_{k}^{*}$ and the cooling efficiency $\mathrm{C}_{k}^{f}$. Several experiments have been done to determine $v$, and a value of 1.33 is generally used (Imberger 1994). The energy introduced at the water surface results from the energy input from both surface cooling and wind shear. The energy flux $\mathrm{F}_{\mathrm{q}}$ can be parameterized as a function of $\eta, \mathrm{F}_{\mathrm{q}}$ $=0.5 \eta^{3}$ (Kim 1976), from which it is possible to estimate the energy dissipation $\varepsilon$ by using $\varepsilon=2 \mathrm{~F}_{\mathrm{q}} / \mathrm{h}$ (Imberger 1985), which will be indicative of the turbulent intensity in the water column. Values of $\varepsilon \sim 10^{-6} \mathrm{~m}^{2} \mathrm{~s}^{-3}$ are indicative of strong turbulence as a result of periods of high wind forcing (MacIntyre et al. 1999; MacIntyre et al. 2002). In contrast, values of $\varepsilon \sim 10^{-7} \mathrm{~m}^{2} \mathrm{~s}^{-3}$ indicate moderate turbulence levels caused by the weak winds.

\section{Results}

Meteorological data show differences between the July and September surveys. The air temperature is higher in July (Fig. 2a) than it is in September (Fig. 2b). In the July survey the air temperature oscillated between $32^{\circ} \mathrm{C}$ and $15^{\circ} \mathrm{C}$ (Fig. 2a), whereas in September the oscillation was between $24^{\circ} \mathrm{C}$ and $15^{\circ} \mathrm{C}$ (Fig. 2b). In both surveys, the surface temperature decreased at night, indicating that this layer loses heat to the air. In July, the air is $5^{\circ} \mathrm{C}$ warmer than the water during the day, whereas in the evening when the wind velocity decreases, the air temperature drops to values $10^{\circ} \mathrm{C}$ below the water temperature. In September, during the day the air temperature is between $1^{\circ} \mathrm{C}$ and $3{ }^{\circ} \mathrm{C}$ warmer than the water, and at night the air temperature drops again to values $5^{\circ} \mathrm{C}$ below the water temperature. Therefore, the difference between the water and air temperatures is lower in September than in July. A similar day-night temperature pattern was also found by Imberger (1985); however, in his work the air temperature is approximately the same as the water temperature during the day, and at night he found a temperature difference between the air and water of $\sim 12^{\circ} \mathrm{C}$. Short-wave radiation is slightly greater in July than in September (Fig. 2c,d, respectively) with only slight variations caused by cumulus clouds passing overhead. It must be pointed out that sunrise in July was earlier $(\sim 04: 00 \mathrm{~h})$ than in September $(\sim 06: 00 \mathrm{~h})$. Sunset in September was slightly earlier $(\sim 17: 00 \mathrm{~h})$ than in July $(\sim 18: 00 \mathrm{~h})$. Relative humidity shows a similar pattern in both surveys (Fig. 2e,f): it was lowest during the morning and afternoon and reached a maximum of $100 \%$ at night. Around midday, the wind direction was $\sim 250-300^{\circ}$ (Fig. $2 \mathrm{~g}, \mathrm{~h}$ ), thus blowing from the river to the dam of the reservoir, whereas in the evening the wind reversed to $\sim 0-50^{\circ}$, thus blowing from the dam to the main body of the reservoir. In the morning hours, its direction reversed again to $\sim 250-300^{\circ}$. In both surveys weak winds prevailed with maximum values of $3 \mathrm{~m} \mathrm{~s}^{-1}$ during the day. On the first day of the September survey, the wind started to blow earlier (at 03:00 h) than in July, with values of $\sim 2.5 \mathrm{~m} \mathrm{~s}^{-1}$, and it persisted during the day until it decreased at night.

Results of the latent heat of evaporation, the sensible heat, the net long-wave radiation, and the net surface heat flux for the July and September surveys were calculated as indicated in the Methods section and are represented in Fig. 3a,b, respectively. In July, heat fluxes ranged from $-130 \mathrm{~W} \mathrm{~m}^{-2}$ to $+30 \mathrm{~W} \mathrm{~m}^{-2}$ (Fig. 3a), whereas in September they ranged from $-60 \mathrm{~W} \mathrm{~m}^{-2}$ to $10 \mathrm{~W} \mathrm{~m}^{-2}$ (Fig. 3b). Sensible heat is slightly larger in July than in September. In July, the sensible heat has positive values during the day, contributing to the heating of the lake, whereas in September it is negative nearly all day, contributing to the heat loss. Long-wave radiation shows a large variation during the day-night survey in July, whereas in September the variation is smaller. The fact that the air temperature is $5^{\circ} \mathrm{C}$ higher than the water temperature during the day results in a positive value of the net long-wave radiation (Fig. 3a,b) during the day. At night, the net long-wave radiation is negative because of the fact that the water is $10^{\circ} \mathrm{C}$ warmer than the air. In both surveys, the effective heat flux at night is dominated by the net longwave radiation because the latent heat flux is low as a result of the weak winds blowing during these hours. The effective heat flux is negative at night (with values down to $-105 \mathrm{~W}$ $\mathrm{m}^{-2}$ in July and $-60 \mathrm{~W} \mathrm{~m}^{-2}$ in September, see Fig. 3c,d, respectively), which leads to mixing. The effective heat flux was positive during the day (with maximum values of $1,058 \mathrm{~W} \mathrm{~m}^{-2}$ in July and 2,069 $\mathrm{W} \mathrm{m}^{-2}$ in September, see Fig. 3c,d) enabling surface-water stratification.

Low values of $\mathrm{w}^{*}$ were found for both the July (Fig. 3e) and September (Fig. 3f) surveys. Convection dominates during the evening and night, with maximum values of $5 \mathrm{~mm} \mathrm{~s}^{-1}$, and becomes zero during the day. The convective period was slightly longer in July, extending from 14:00 $\mathrm{h}$ on the first day to $07: 00 \mathrm{~h}$ on the second day, than in September, when it extended from 16:00 $\mathrm{h}$ on the first day to $07: 00 \mathrm{~h}$ on the second day. Low values of surface-layer velocity $\left(\mathrm{u}^{*}\right)$ were also found in both the July (see Fig. 3e) and September (Fig. 3f) surveys. In the July survey, $\mathrm{u}^{*}$ decreased at night, and it reached its lowest values of $0.001 \mathrm{~m} \mathrm{~s}^{-1}$ from 21:00 $\mathrm{h}$ until 05:00 h, and then it increased again. In contrast, in the September survey, $u^{*}$ had a smaller oscillation range, which went from $0.001 \mathrm{~m} \mathrm{~s}^{-1}$ to $0.003 \mathrm{~m} \mathrm{~s}^{-1}$. In July, values of the dissipation rate $(\varepsilon)$ were found to be between low $(1 \times$ $\left.10^{-9} \mathrm{~m}^{2} \mathrm{~s}^{-3}\right)$ to moderate $\left(1 \times 10^{-7} \mathrm{~m}^{2} \mathrm{~s}^{-3}\right)$ with mean values of $\sim 5 \times 10^{-8} \mathrm{~m}^{2} \mathrm{~s}^{-3}$ in the late afternoon and night time (Fig. 3g). In contrast, in September, $\varepsilon$ was slightly smaller, (between $1 \times 10^{-9} \mathrm{~m}^{2} \mathrm{~s}^{-3}$ and $3 \times 10^{-8} \mathrm{~m}^{2} \mathrm{~s}^{-3}$ ) with mean values of $3 \times 10^{-8} \mathrm{~m}^{2} \mathrm{~s}^{-3}$ in the late afternoon and night time hours (Fig. 3h). In both surveys, the largest values were found during the late afternoon and night time hours as a result of the mixing caused by the night cooling of the surface. During the day, because winds are very weak, the dissipation rates are lower than at night.

In July, the water column was stratified from the top of the water column downward (Fig. 4a), which illustrates a shallow-surface mixing layer at the top of the water 

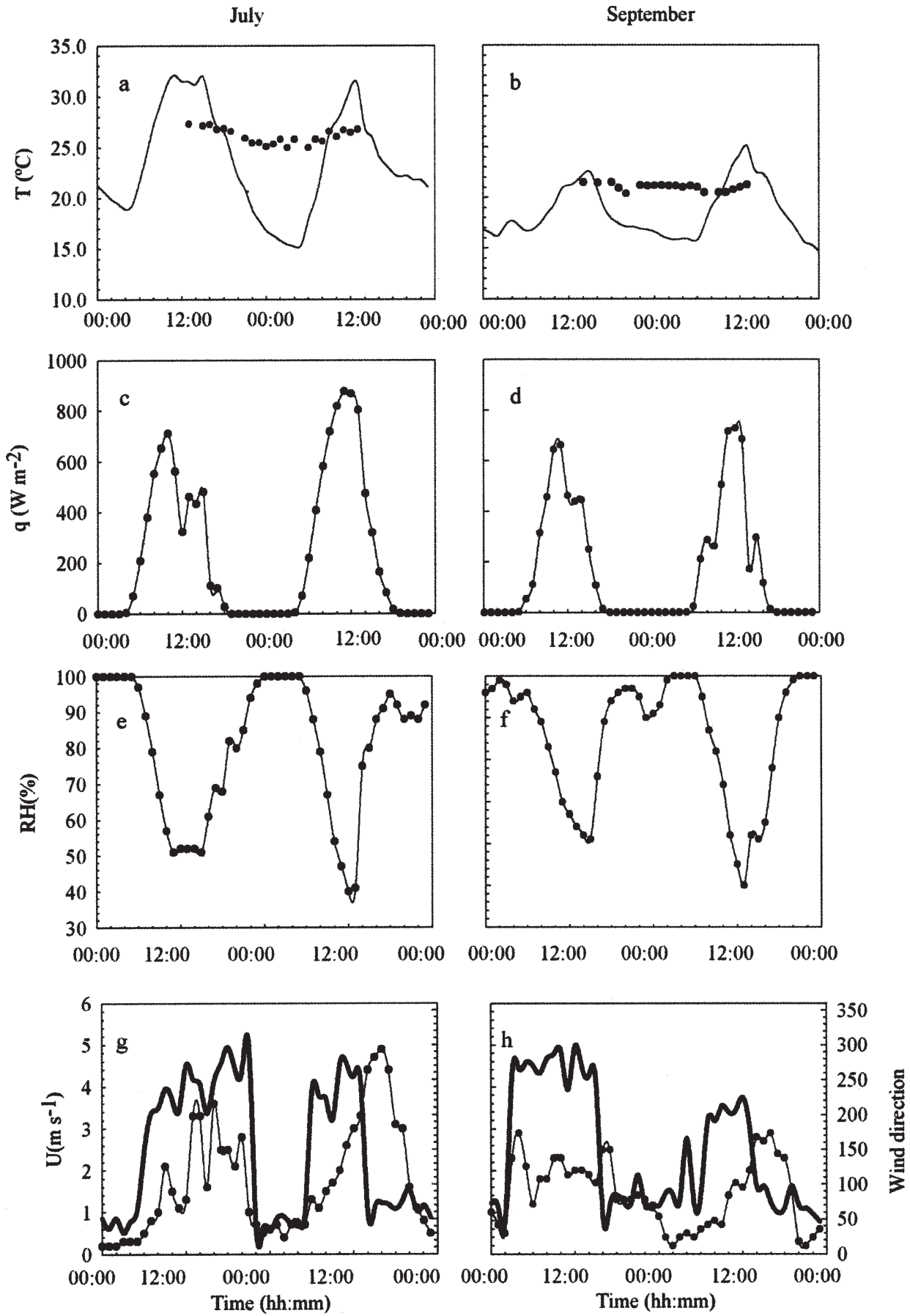

Fig. 2. For the July and September surveys, $(a, b)$ surface-water temperature (circles) and air temperature (line); (c, d) short-wave radiation; (e, f) relative humidity; and (g, h) wind velocity (thin line) and wind direction (thick line).

column. The surface mixing layer increased from 1-m depth in the late afternoon to 4-m depth at night and early morning. During the day, a mixing layer 2-m deep was reestablished again (see the profile taken at 11:00 $\mathrm{h}$ in Fig. 4a). Three different phytoplankton communities were found in the water column during both surveys (July and September): green algae, diatoms, and cryptophyceae. In the July survey just a few exemplars of blue green algae were found, always in low concentrations (with values
$<3 \mathrm{mg} \mathrm{m}^{-2}$ ) integrated over the entire water column. Green algae were the most abundant and were found from the surface of the water column down to $10-\mathrm{m}$ deep (Fig. 4b). Vertical profiles of green algae show a surface layer with a constant value of chlorophyll ranging from $6 \mu \mathrm{g} \mathrm{L}^{-1}$ to $12 \mu \mathrm{g} \mathrm{L}^{-1}$. The depth of this layer changes with time, attaining the deepest value $(\sim 4 \mathrm{~m})$ at night (see 04:00 h profile, Fig. $4 \mathrm{~b}$ ). At sunrise, the layer shallows and reaches the shallowest depth at noon. Below this layer, the 

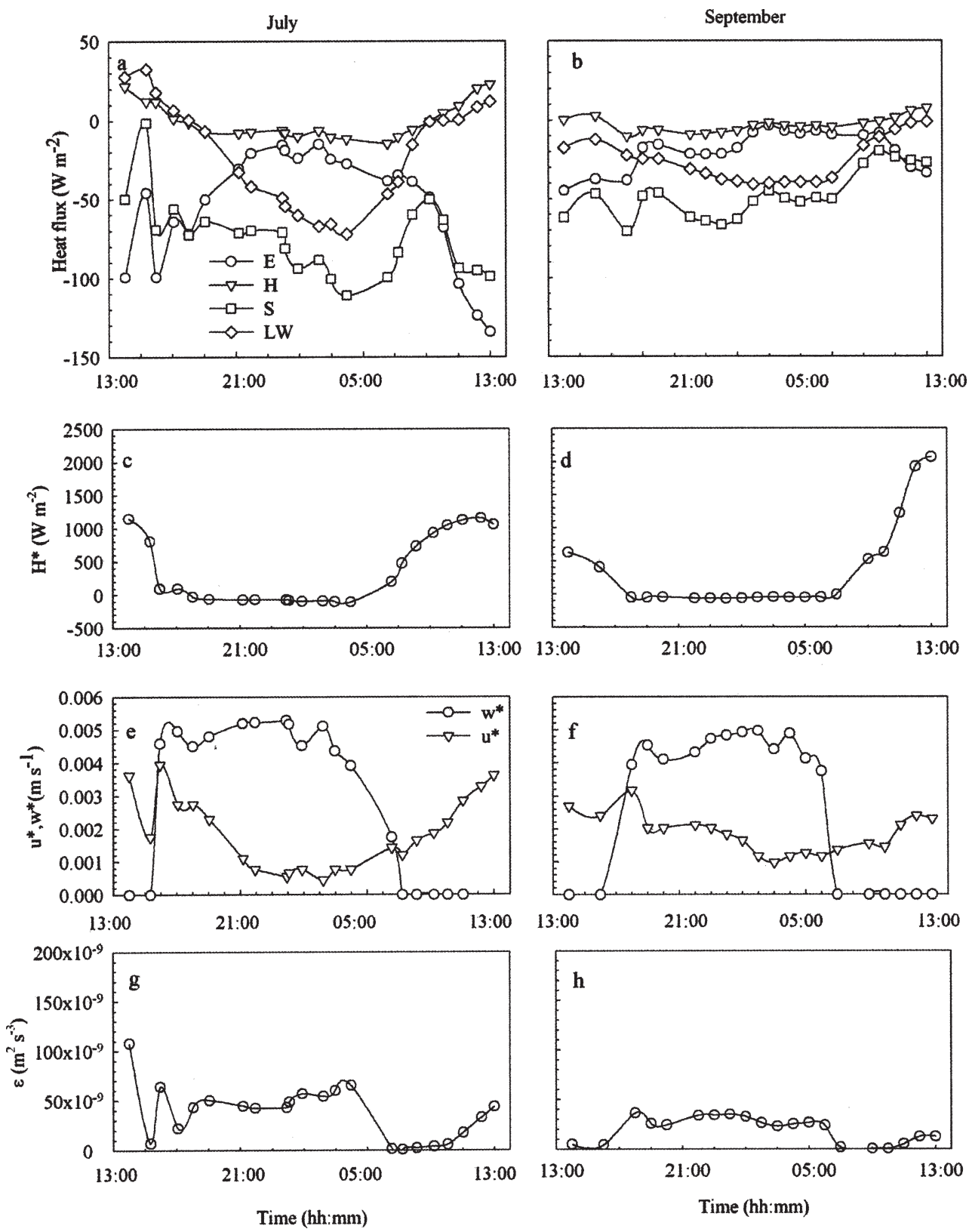

Fig. 3. For the July and September surveys, (a, b) latent heat of evaporation (E), sensible heat $(\mathrm{H})$, net long-wave radiation (LW), and net surface heat flux omitting the short-wave radiation $(\mathrm{S})$; (c, d) effective heat flux $\left(\mathrm{H}^{*}\right)$; $(\mathrm{e}, \mathrm{f})$ penetrative convection velocity $\left(\mathrm{w}^{*}\right)$ and surfacelayer velocity induced by the wind $\left(\mathrm{u}_{\mathrm{w}}{ }^{*}\right)$; and $(\mathrm{g}, \mathrm{h})$ rates of energy dissipation $(\varepsilon)$ averaged across the mixing layer depth.

green algae population has a peak of maximum concentration located at a depth that varies with time. This maximum is $\sim 5$ - $\mathrm{m}$ deep at 19:00 $\mathrm{h}$, after which it deepens to $\sim 6 \mathrm{~m}$ and remains at this depth until the morning hours when the population forms a subsurface peak of $16 \mu \mathrm{g} \mathrm{L}^{-1}$ at a depth of $\sim 2 \mathrm{~m}$ (see the profile taken at $11: 00 \mathrm{~h}$ in Fig. 4b). Diatoms are distributed from the surface to a depth of $5 \mathrm{~m}$ (Fig. 4c). During the day, diatoms form a subsurface peak at around 2-m depth, whereas at night they are homogeneously distributed in a 4-m-thick surface layer. Cryptophyceae show a pattern similar to diatoms
(Fig. 4d). During the day they form a subsurface peak of 4 $6 \mu \mathrm{g} \mathrm{L}^{-1}$, which is located at a depth of around $2 \mathrm{~m}$ (see the profile taken at $14: 00 \mathrm{~h}$ in Fig. $4 \mathrm{~d}$ ). This pattern changes at night when vertical profiles of fluorescence show a constant value of $2 \mu \mathrm{g} \mathrm{L}^{-1}$ in a layer 4-m thick located at the surface of the water column.

In September, the temperature gradient is not as continuous as it is in July, and the temperature profile is close to a three-layer pattern: epilimnion, metalimnion, and hypolimnion (Fig. 5a). It has to be pointed out that the hypolimnion is still slightly stratified, although it is not 

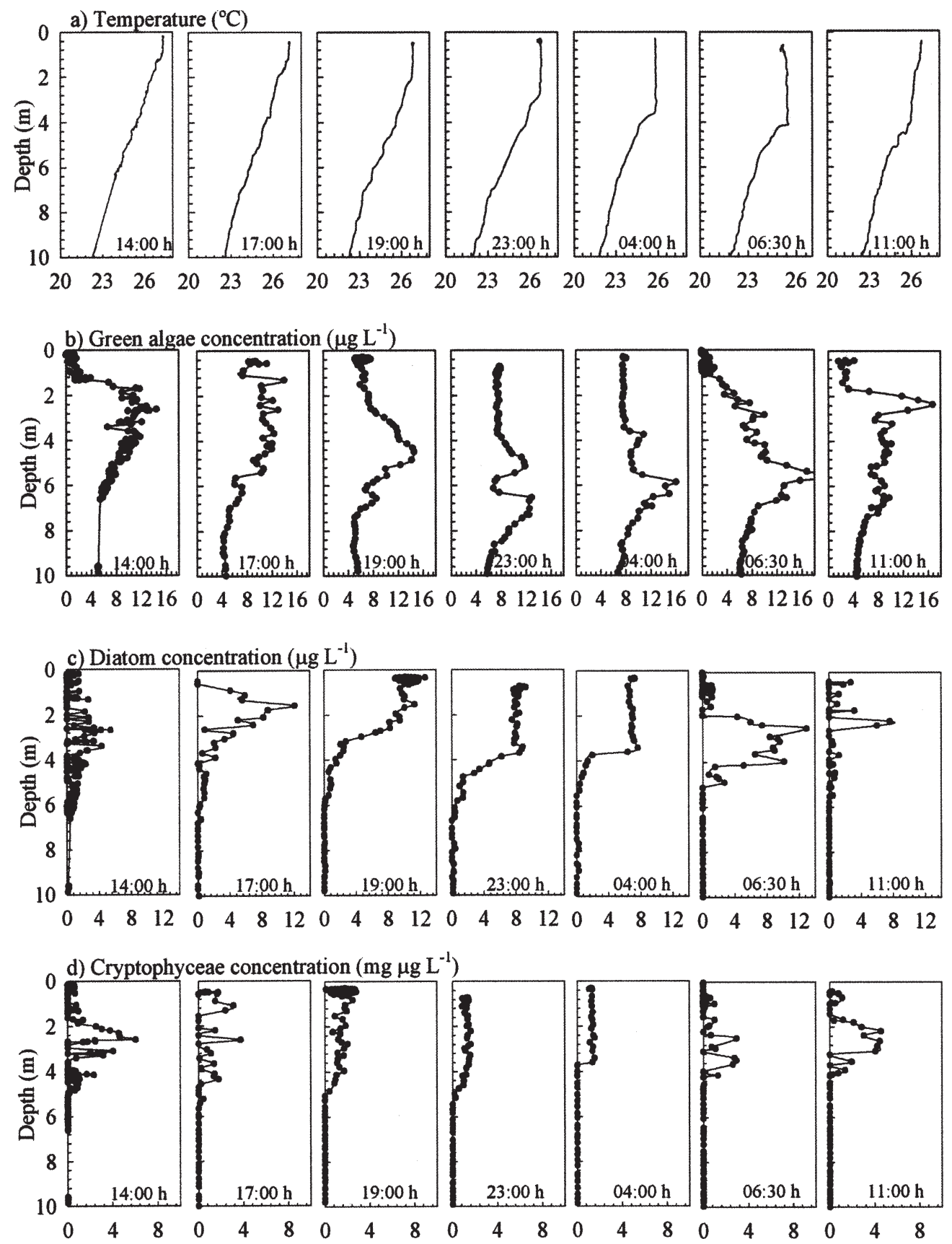

Fig. 4. Selected profiles of (a) temperature, (b) green algae concentration, (c) diatom concentration, and (d) cryptophyceae from the day-night survey carried out in July 2003.

shown in Fig. 5a. The epilimnion, which extends from the surface to $\sim 15-\mathrm{m}$ depth, as in July, illustrated surface warming and nocturnal cooling, with the most pronounced effects in the upper $5 \mathrm{~m}$ (Fig. 5a). In the September survey, green algae show similar behavior to that found in July. At the surface of the water column there is a deep layer with a constant chlorophyll value from the beginning of the survey until sunset on the second day. This layer has a thickness of $3 \mathrm{~m}$, which increases to $5 \mathrm{~m}$ for night profiles (Fig. 5b). However, on the second day of the September survey, green algae form a subsurface peak at a shallow depth of $2 \mathrm{~m}$ (see the profile carried out at 12:00 h, Fig. 5b). Below this layer green algae form a second layer with approximately constant chlorophyll values. The bottom of this layer extends down to $12-\mathrm{m}$ depth on the first day (see the 13:15 h profile, Fig. 5b) and shallows to 9$\mathrm{m}$ depth on the second day (see the 12:00 $\mathrm{h}$ profile in Fig. 5b). In September, diatoms show a surface maximum decreasing slightly to $3 \mathrm{~m}$ depth for the daytime vertical profiles (Fig. 5c). For night profiles this pattern breaks down, and diatoms distribute homogeneously throughout a surface layer that attains its deepest value at $4 \mathrm{~m}$ (see the 
a) Temperature $\left({ }^{\circ} \mathrm{C}\right)$
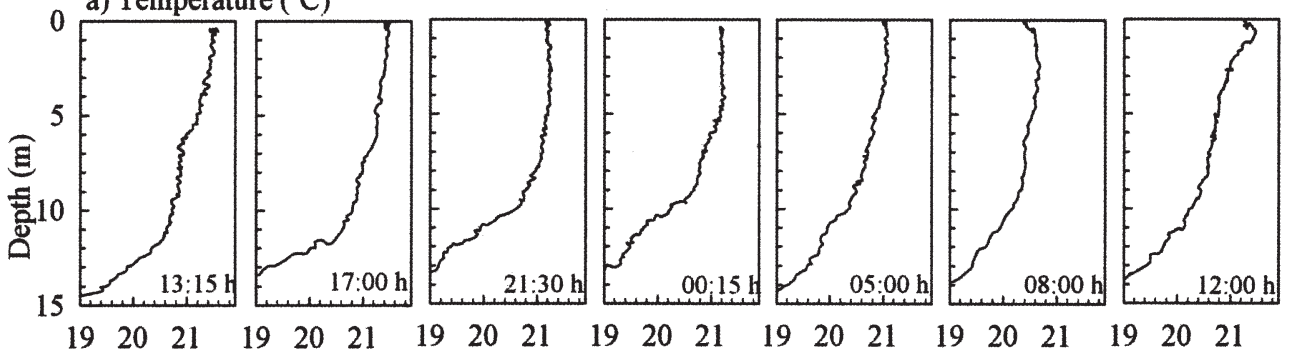

b) Green algae concentration $\left(\mu \mathrm{g} \mathrm{L}^{-1}\right)$
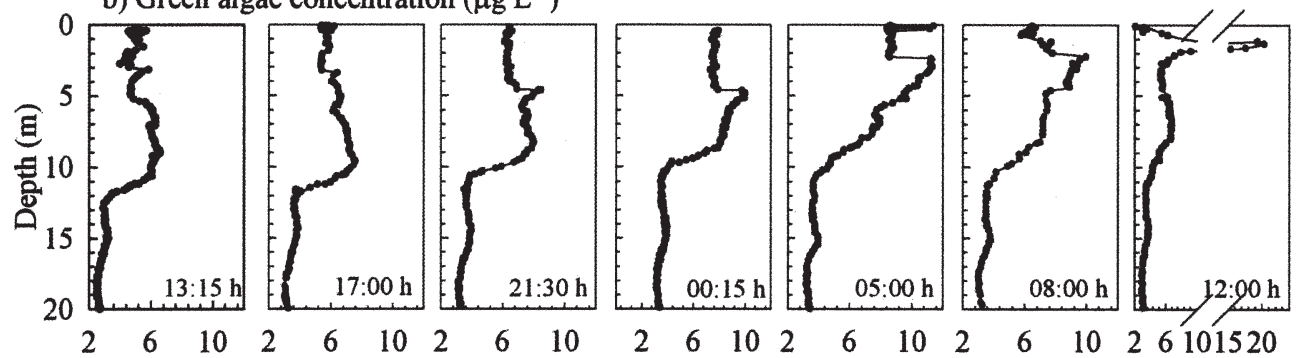

c) Diatom concentration $\left(\mu \mathrm{g} \mathrm{L}^{-1}\right)$

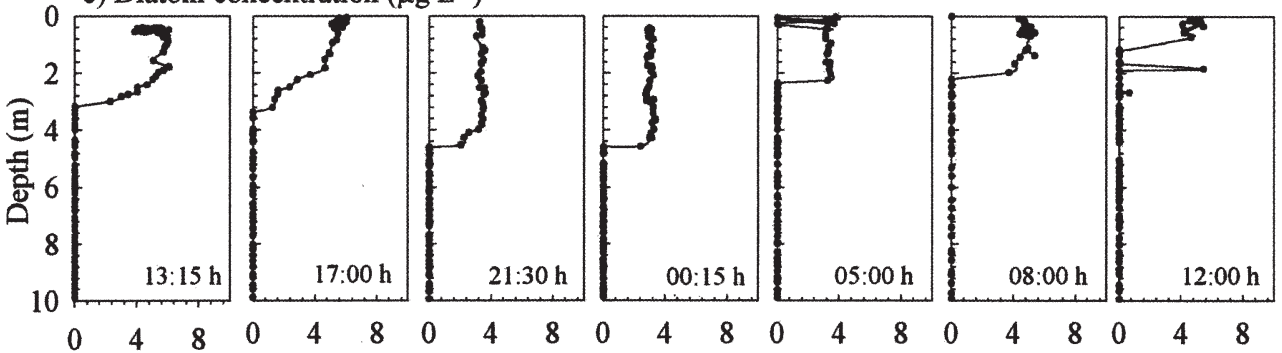

d) Cryptophyceae concentration $\left(\mu \mathrm{g} \mathrm{L}^{-1}\right)$
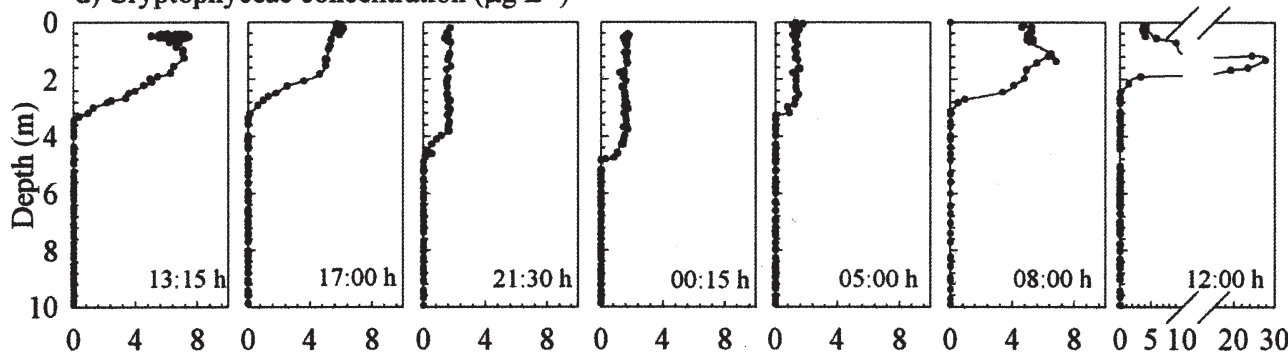

Fig. 5. Selected profiles of (a) temperature, (b) green algae concentration, (c) diatom concentration, and (d) cryptophyceae from the day-night survey carried out in September 2003.

profile carried out at 00:15 h in Fig. 5c). At sunrise this layer becomes shallower, reaching a thickness of $2 \mathrm{~m}$ (see the profile carried out at 12:00 h in Fig. 5c). Cryptophyceae show similar behavior to diatoms. During the daytime hours on the first day, they are at a maximum at the surface and decrease with depth down to $4 \mathrm{~m}$ (Fig. 5d). At night this pattern breaks down and they are homogeneously distributed (see the profile carried out at $00: 15 \mathrm{~h}$ in Fig. 5d). On the second day, cryptophyceae move to a shallower depth and form a subsurface peak located at $\sim 1-\mathrm{m}$ depth (see the profile carried out at 12:00 $\mathrm{h}$ in Fig. 5d).

From the vertical profiles shown in Figs. 4 and 5 we can obtain the depth of the mixed layer according to each phytoplankton community (green algae, diatoms, and cryptophyceae). The time evolution of this interface has been represented in Fig. 6a for the July survey and in Fig. $6 \mathrm{~b}$ for the September survey. It can be seen that the interface of each community deepens at night to around $5 \mathrm{~m}$ in both surveys and becomes shallower during the day, reaching similar depths in both the July and September surveys and following the same dynamics as temperature (Fig. 6a,b). Therefore, the behavior of the interface of each community coincides with the behavior of the mixing layer.

If we now integrate the concentration of chlorophyll for the three phytoplankton communities across the entire water column, hereafter known as the total concentration of chlorophyll per square area, it can be observed that in July the total concentration of green algae increases slightly from $120 \mathrm{mg} \mathrm{m}^{-2}$ at the beginning of the survey, attains 


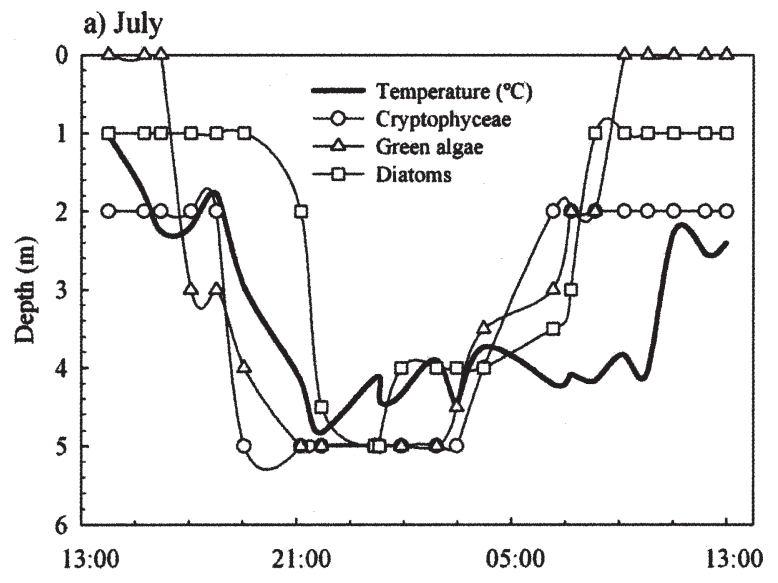

b) September

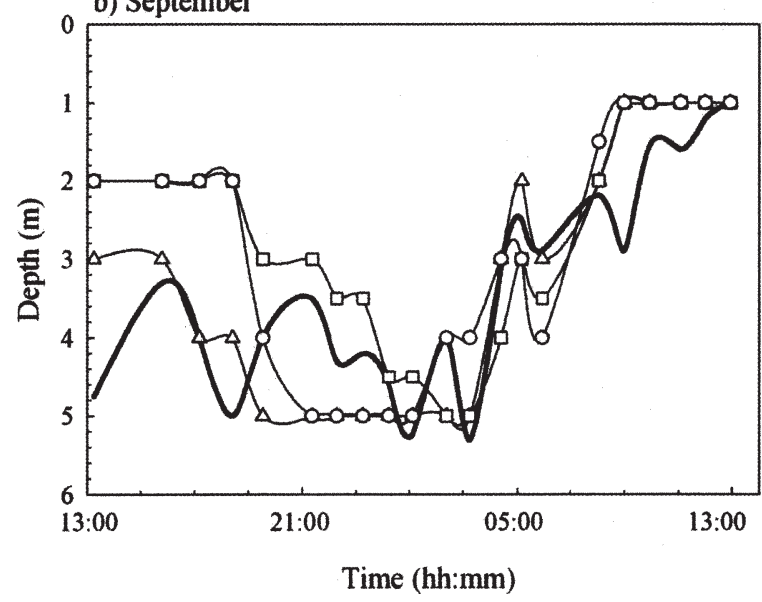

Fig. 6. Interface depth for green algae, diatoms, and cryptophyceae and thermocline (thick solid line) for (a) July and (b) September surveys.

a maximum of $156 \mathrm{mg} \mathrm{m}^{-2}$ at night, and then decreases slightly to $110 \mathrm{mg} \mathrm{m}^{-2}$ on the second day (Fig. 7a). In contrast, in the September survey green algae shows the same increase from day to night, but from the night to the second day it remains approximately constant until the end of the survey. In July, diatoms increase from a value of $9 \mathrm{mg} \mathrm{m}^{-2}$ to a maximum of $40 \mathrm{mg} \mathrm{m}^{-2}$ at night (Fig. 7b), then decrease again to their initial value on the second day.
In September, diatoms decrease slightly and continuously from $15 \mathrm{mg} \mathrm{m}^{-2}$ on the first day to approximately $5 \mathrm{mg} \mathrm{m}^{-2}$ on the second day. In July, the total cryptophyceae concentration begins at $5 \mathrm{mg} \mathrm{m}^{-2}$ on the first day and then decreases slightly to $1 \mathrm{mg} \mathrm{m}^{-2}$ on the second day (Fig. 7c), whereas in September it decreases from $15 \mathrm{mg} \mathrm{m}^{-2}$ and reaches the lowest value of approximately $5 \mathrm{mg} \mathrm{m}^{-2}$ at night. From this point onward the concentration increases strongly, reaching values of $30 \mathrm{mg} \mathrm{m}^{-2}$ at 13:00 $\mathrm{h}$ on the second day (Fig. 7c).

In the July survey, the flow-velocity contours show layers with alternate values of the velocity direction (Fig. 8a). Since contours are first drawn 2 days before the field survey, it is possible to observe how the velocity direction of the surface layers reverses with time. We focused our attention on the layer located between 3-m and $10-\mathrm{m}$ depth because this is where the main phytoplankters are distributed (see the right panels in Fig. 8a,b). In July during the day there is a layer between 4-m and 9-m depth that has negative velocity values in the range of $-2 \mathrm{~cm} \mathrm{~s}^{-1}$ to $-8 \mathrm{~cm} \mathrm{~s}^{-1}$, which indicates that water flows from the dam to the main body of the reservoir, in the opposite direction to the wind. The water in the surface layer is expected to flow in the same direction as the wind and the layer below it to flow in the opposite direction, i.e., it should be the countercurrent of the surface current. At night, this layer flows in the reverse direction, from the main body of the reservoir to the dam, also in the opposite direction to the wind, and has values between $2 \mathrm{~cm} \mathrm{~s}^{-1}$ and $6 \mathrm{~cm} \mathrm{~s}^{-1}$ (Fig. 8a). In September, the depth of the maximum flow velocity became shallower, from 12-m deep at 20:00 $\mathrm{h}$ to $6 \mathrm{~m}$ at 07:00 $\mathrm{h}$ and remained at this depth flowing toward the dam until the end of the studied period (Fig. 8b).

Isotherms of $25,24,23,22,21,19$, and $17^{\circ} \mathrm{C}$ for the July survey and isotherms of $21.4,21.2,21,20,19,17$, and $14^{\circ} \mathrm{C}$ for the September survey show oscillations (Fig. 8a,b, respectively), which indicate the presence of standing internal waves (or seiches) in the reservoir. The fact that wind has a 24-h periodicity, close to the natural period of the V3H1 mode, favors the excitation of this mode in September (Vidal et al. 2005). However, in July the predominant mode is the $\mathrm{V} 2 \mathrm{H} 1$ mode, which has a natural period of $12 \mathrm{~h}$.
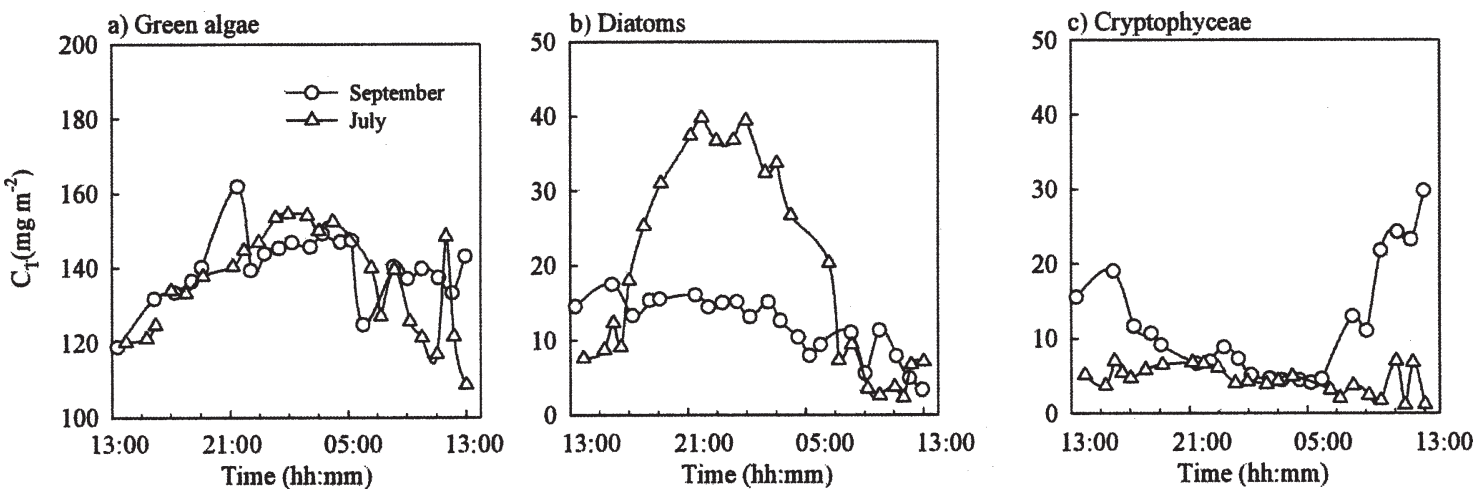

Fig. 7. Total concentration of (a) green algae, (b) diatoms, and (c) cryptophyceae for both the July and September surveys. 
a) July

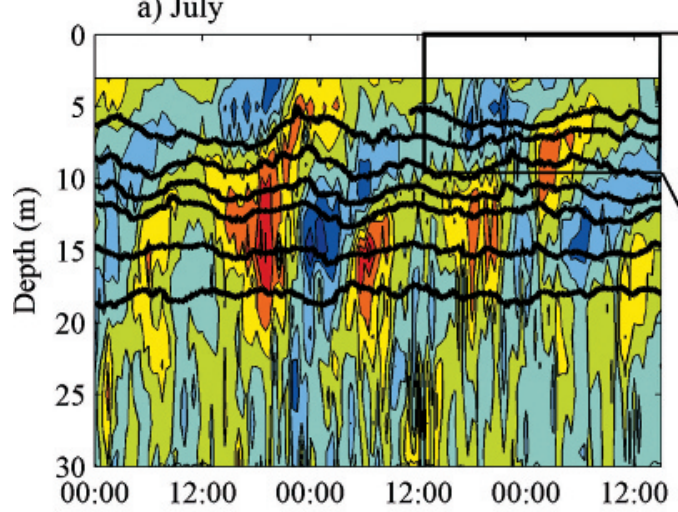

b) September

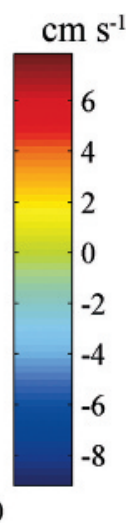

$\mathrm{cm} \mathrm{s}^{-1}$
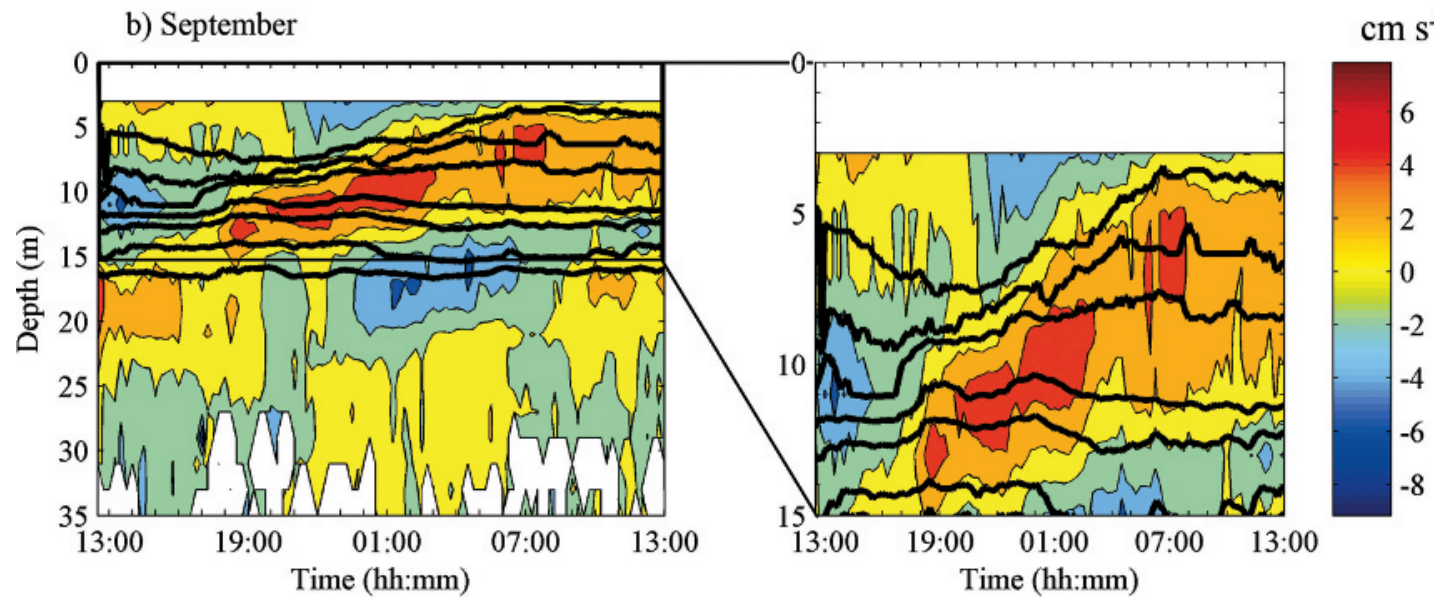

Fig. 8. Velocity contours measured with the ADCP at S2 (see Fig. 1) for the (a) July and (b) September field surveys. Wind and velocity were projected following the main axis of the reservoir. Black lines represent the time evolution of some selected isotherms (from top to bottom) July: $25,24,23,22,21,19$, and $17^{\circ} \mathrm{C}$; September: $21.4,21.2,21,20,19,17$, and $14^{\circ} \mathrm{C}$.

\section{Discussion}

Since July corresponds to the beginning and September corresponds to the end of the summer season, the water column has different stratification patterns in each survey. In September, the stratification corresponds to the usual pattern at the end of the stratified period for lakes in the Mediterranean area in which epilimnion, metalimnion, and hypolimnion layers (Fig. 5a) can be clearly distinguished. In July, the water column is continuously stratified from the surface to the bottom (Fig. 4a); this stratification is characteristic of the usual pattern for the beginning of the stratified period. Sau reservoir is located in a region with low wind speeds. As a result, latent heat, which usually dominates surface energy budgets, is low, giving low values of $\mathrm{w}^{*}$. MacIntyre et al. (2002) found values in Lake Victoria between two and three times the $\mathrm{w}^{*}$ values found in the Sau reservoir (Fig. 3e,f). The difference can be attributed to the fact that in Lake Victoria the effective heat flux at night is dominated by the latent heat flux, which is larger than in Sau reservoir as winds in Lake Victoria are stronger $\left(\sim 4 \mathrm{~m} \mathrm{~s}^{-1}\right.$ and peaking with $\left.10 \mathrm{~m} \mathrm{~s}^{-1}\right)$ compared to the winds blowing in Sau reservoir (remaining at the minimum of $1 \mathrm{~m} \mathrm{~s}^{-1}$ ). In Imberger (1985) values of $\mathrm{w}^{*}$ were found between 1.5-2× greater than in Sau reservoir.
The difference can also be attributed to the difference in the wind velocity. Low wind speeds will also result in low values of $\mathrm{u}^{*}$ (Fig. 3e,f). Values of $\mathrm{u}^{*}$ two and three times those of the present work were found by Imberger (1985) and MacIntyre et al. (2002). The dissipation energy ( $(\varepsilon)$ averaged over the surface mixing layer was found, in general, to be of the order of $5 \times 10^{-8} \mathrm{~m}^{2} \mathrm{~s}^{-3}$ (in July, Fig. $3 \mathrm{~g}$ ) and $3 \times 10^{-8} \mathrm{~m}^{2} \mathrm{~s}^{-3}$ (in September, Fig. 3h), which indicates that the mixed layer is between low and moderately turbulent. Values two times larger were found in Lake Biwa, where winds are below $4 \mathrm{~m} \mathrm{~s}^{-1}$ (MacIntyre, 1998). For larger wind speeds $\left(\sim 6-8 \mathrm{~m} \mathrm{~s}^{-1}\right)$, dissipation rates were found of the order of $10^{-6} \mathrm{~m}^{2} \mathrm{~s}^{-3}$, which indicates strong turbulence levels (MacIntyre et al. 2002). Similar to the results found in the present work, Brainerd and Gregg (1993) found maximum dissipation rates of $\sim 3$ $\times 10^{-8} \mathrm{~m}^{2} \mathrm{~s}^{-3}$ for light wind periods (with wind velocities of $\left.\sim 2 \mathrm{~m} \mathrm{~s}^{-1}\right)$ in the mixed layer of the open ocean. In contrast, when winds were stronger $\left(\sim 8 \mathrm{~m} \mathrm{~s}^{-1}\right)$, dissipation rates were found in the order of $10^{-7} \mathrm{~m}^{2} \mathrm{~s}^{-3}$. In the present work it can be observed that at night the depth of the mixed layer is determined by two mechanisms: the mixing caused by the net night cooling and the internal oscillations that move isotherms up and down in the water column (as can be seen from the isotherms in Fig. 8a,b). In contrast, during 

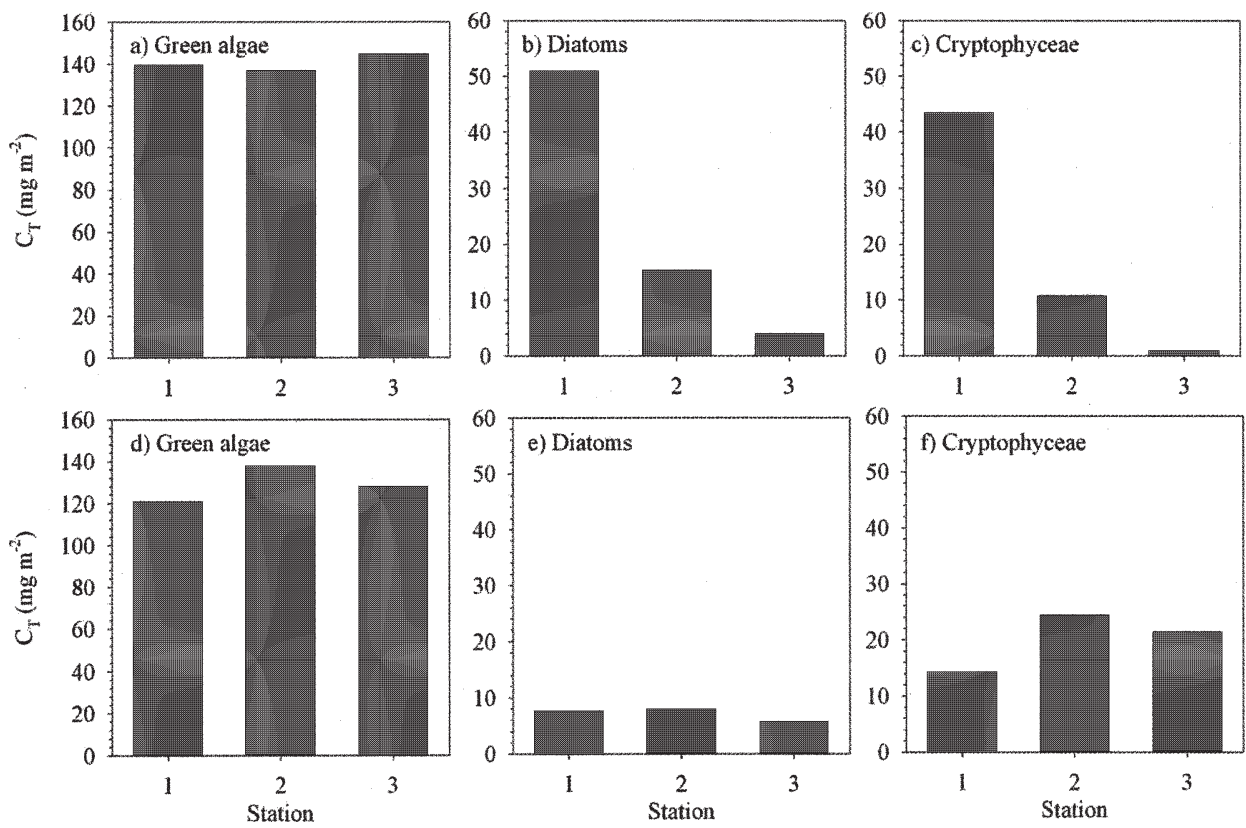

Fig. 9. The total concentration of (a) green algae, (b) diatoms, and (c) cryptophyceae at different measured stations on 24 September at 18:25 h, and the total concentration of (d) green algae, (e) diatoms and (f) cryptophyceae at different measured stations on 25 September at 11:30 h.

the day this depth is determined by both solar heating and internal oscillations (see Fig. 8a,b). Because the wind is weak during the night and day, it does not contribute substantially to the deepening of the mixed layer.

During the night the phytoplankton concentration is constant throughout the entire surface layer, which indicates that phytoplankton cells are well mixed. The homogeneous vertical distribution found at night can be attributed to the convective process, which has been found to be dominant over the mixing induced by the wind (Fig. 3e,f). The convective velocity caused by night cooling was found to be $0.5 \mathrm{~cm} \mathrm{~s}^{-1}, 50$ times the swimming velocity of motile organisms $\left(\mathrm{v}_{\mathrm{s}}\right)$, whose velocity is at best in the range of $0.01 \mathrm{~mm} \mathrm{~s}^{-1}$ to $0.1 \mathrm{~mm} \mathrm{~s}^{-1}$ (Reynolds 1984). Thus, all the phytoplankton groups follow the flow dynamics. The ratio between the velocity scale of mixing and the velocity scale of the motile organisms is equivalent to the Peclet number, $\mathrm{Pe}=\mathrm{v}_{\mathrm{s}} / \mathrm{w}^{*}$ ) (O'Brien et al. 2003). Using the velocity values found in the present study, Pe ranges from 0.002 to 0.02 , which is less than 0.1 , indicating that the phytoplankton are uniformly distributed (O'Brien et al. 2003). This is in accordance with the constant value for the phytoplankton concentration in the surface mixing layer during the night (see Figs. 4b-d, 5b-d). In addition, persistent stratification below the depth of the surface mixing layer enables the development and persistence of layers of green algae, which is the phytoplankton community that extends deepest in the water column. In contrast, during the day and because of the weak mixing, phytoplankton redistributes vertically and accumulates at certain depths forming thin phytoplankton layers (Figs. 4, 5). There are two main mechanisms that contribute to the vertical redistribution of phytoplankton and the rising of isotherms at S2: the solar heating and the internal oscillations. The last process can be observed particularly when comparing the phytoplankton profiles in the September survey (Fig. 5b-d) with the vertical displacement of isotherms (Fig. 8b). The upper interface of green algae and the lower interfaces for diatoms and cryptophyceae sink from $3 \mathrm{~m}$ to $5 \mathrm{~m}$ from $13: 15 \mathrm{~h}$ to $21: 30 \mathrm{~h}$ and rise from $5 \mathrm{~m}$ to $2 \mathrm{~m}$ from $21: 30 \mathrm{~h}$ to $12: 00 \mathrm{~h}$, respectively, which coincides with the vertical displacement of isotherms. In particular, in September the uppermost isotherm (Fig. 8b) sinks from $5 \mathrm{~m}$ to $7 \mathrm{~m}$ and then rises from $7 \mathrm{~m}$ to $4 \mathrm{~m}$ for the same periods, respectively.

The changes in time of the total concentration of phytoplankton observed at S2 (Fig. 7) can be attributed to horizontal advection caused by wind-driven currents and internal oscillations. If the phytoplankton were heterogeneously distributed horizontally, forming patches of different phytoplankton concentrations throughout the reservoir, the horizontal movement could explain the change in the total concentration of each phytoplankton group (Fig. 7). This cannot be tested for the July survey, when the measurements were only taken at S2. However, measurements of phytoplankton at two more stations of the reservoir ( $\mathrm{S} 1$ and $\mathrm{S} 3$, see Fig. 1) were taken in the September survey, and the results show differences in the horizontal distribution of each phytoplankton community (Fig. 9). These results may be due to the fact that there are sites along the reservoir with different phytoplankton growth rates because of different habitat conditions. It must be pointed out that this patchiness might be maintained by the spatial variability of heating during the day as well as by possible differences in the nutrient load at different stations of the reservoir. Values of the total concentration of each phytoplankton group are shown in Fig. 9 for the different stations. Four more measurements 
at different times were carried out at these stations and all of them showed similar results (results not shown). Although green algae seem to have a homogeneous distribution (Fig. 9a), horizontal heterogeneities are mainly observed for diatoms (Fig. 9b) and cryptophyceae (Fig. 9c). Spatial heterogeneities have been found previously by other authors such as Dickman et al. (1993), who reported spatial heterogeneities or patchiness of phytoplankton in a lake in northern Iceland; by Einarsson et al. (2004), who reported spatial heterogeneities in the phytoplankton distribution in Lake Myvatn; and by Cloern (1991), who reported horizontal heterogeneities in the South San Francisco Bay. In addition, a mean value of the phytoplankton growth rate of 0.3 cells day ${ }^{-1}$ (Bormans and Condie 1998; Baker et al. 2000; Serra et al. 2003; results in an increase in the total concentration of chlorophyll ranging from $120 \mathrm{mg} \mathrm{m}^{-2}$ to $156 \mathrm{mg} \mathrm{m}^{-2}$ for green algae, from $10 \mathrm{mg} \mathrm{m}^{-2}$ to $13 \mathrm{mg} \mathrm{m}^{-2}$ for diatoms, and from $5 \mathrm{mg} \mathrm{m}^{-2}$ to $6.5 \mathrm{mg} \mathrm{m}^{-2}$ for cryptophyceae. Therefore, this increase cannot account for the large increase in green algae from $120 \mathrm{mg} \mathrm{m}^{-2}$ to $160 \mathrm{mg} \mathrm{m}^{-2}$ (Fig. 7a), from $10 \mathrm{mg} \mathrm{m}^{-2}$ to $40 \mathrm{mg} \mathrm{m}^{-2}$ for diatoms (Figure 7b), and from $5 \mathrm{mg} \mathrm{m}^{-2}$ to $30 \mathrm{mg} \mathrm{m}^{-2}$ for cryptophyceae (Fig. 7c).

Horizontal velocities reached maximum values of $\sim 8 \mathrm{~cm} \mathrm{~s}^{-1}$ (Fig. 8), which are 16 times the convective velocity and 800 times the swimming velocity of motile organisms. If we consider a mean horizontal velocity value of $4 \mathrm{~cm} \mathrm{~s}^{-1}$ for the layer between $4 \mathrm{~m}$ and $9 \mathrm{~m}$ in July flowing from the dam to the main body of the reservoir for $6 \mathrm{~h}$ (see Fig. 8a), a total displacement of $864 \mathrm{~m}$ is obtained. This distance coincides with the distance between S1 and S2 (Fig. 1). Therefore, phytoplankton cells can travel from S1 to S2 during the day because of the horizontal advection caused by the wind-driven current and advection caused by internal waves. This could account for the variation in the total phytoplankton concentration (see Fig. $7 \mathrm{a}-\mathrm{c}$ ). When the current reverses with mean values of $2 \mathrm{~cm} \mathrm{~s}^{-1}$ from the reservoir to the dam over $8 \mathrm{~h}$ in July (Fig. 8a), it results in a horizontal displacement of $576 \mathrm{~m}$, which is close to the distance traveled before. In this case, phytoplankton cells go back to their initial position. On the first day of September, the flow again went from S1 to S3 with a mean value of $2 \mathrm{~cm} \mathrm{~s}^{-1}$ over $4 \mathrm{~h}$ (Fig. 8b), which resulted in a horizontal displacement of $288 \mathrm{~m}$. Then, the wind reversed, and similarly, on the second day of September, the wind kept blowing in the same direction all morning, from the reservoir to the dam, with a mean value of $2 \mathrm{~cm} \mathrm{~s}^{-1}$ for $10 \mathrm{~h}$, giving a total displacement of $720 \mathrm{~m}$. In addition, assuming that the surface layer above $3 \mathrm{~m}$ flows in the same direction as the wind, during the day time hours the wind-driven current will transport those phytoplankton cells located within this layer downwind, i.e., toward the dam. This means that diatoms and cryptophyceae would accumulate at S1, which might account for the large concentrations of these populations found at S1 as compared to the concentrations found at S2 and S3 in the late afternoon (at 18:25 h, Fig. 9b,c). When the wind velocity is low and its direction reverses, green algae do not show changes in their total concentration because they are homogeneously distributed (Fig. 9d), whereas diatoms and cryptophyceae redistribute again, attaining similar values at different stations, which can be observed from the total concentration in the morning $(11: 30 \mathrm{~h})$ in Fig. 9e,f.

Although in both surveys cryptophyceae and diatoms only extend to a maximum depth of $4 \mathrm{~m}$ and are mainly dominated by surface processes (like convection and winddriven currents), internal waves were also found to be important in determining their vertical extension. All of these processes have been schematically represented in Fig. 10a for the July survey and in Fig. 10b for the September survey. Green algae extend deeper in the water column than diatoms and cryptophyceae. At deeper layers, green algae are influenced by the effect of internal seiches and the wind-driven current (see Fig. 10a,b). At these depths green algae present layers, possibly because of the low turbulence levels below the surface mixing layer. This fact would explain why during the day in the July survey we found a peak of green algae at $5-\mathrm{m}$ depth (see the profile at 19:00 $\mathrm{h}$ in Fig. 4b) coinciding with the advection of water from the dam to the reservoir with a maximum velocity at the same depth at this time of the day (Fig. 8a). Then, when the flow reverses at 01:00 h (Fig. 8a), the advected water flows from the reservoir to the dam, with the maximum velocity centered at approximately $6.5 \mathrm{~m}$ at $04: 00 \mathrm{~h}$, which corresponds to a maximum green algae concentration (see 04:00 h profile in Fig. 4b) at approximately the same depth. From this time on, this peak of green algae becomes slightly shallower, also following the behavior of the velocity contours and the upward tilting of isotherms caused by the internal oscillations (Fig. 8a,b). In the September survey, green algae also extend from the surface down to $12-\mathrm{m}$ deep. The depth of the bottom of this layer changes with time from $12 \mathrm{~m}$ at $13: 15 \mathrm{~h}$ (Fig. $5 \mathrm{~b}$ ) to $8 \mathrm{~m}$ at $12: 00 \mathrm{~h}$ (Fig. 5b), which coincides with the behavior of the velocity contours and isotherms (see the three first isotherms in Fig. 8b). The maximum of the velocity shallows from 17-m depth at 13:00 $\mathrm{h}$ on the first day to 8-m depth on the second day. For the layer from $3-5 \mathrm{~m}$ deep, the velocity is approximately constant and directed from the reservoir toward the dam from 13:00 h to 19:00 h (Fig. 8b), coinciding with the mixed value for green algae at the surface. From 19:00 h on, this layer shallows slightly with a velocity advected from the dam to the reservoir until 07:00 $\mathrm{h}$, when it probably remains confined to the top of the water column above 3-m depth (Fig. 8b). This velocity pattern coincides with the behavior of green algae that show a homogeneous layer at the surface that shallows slightly from 19:00 h to 12:00 h (Fig. 5b).

Since both light and nutrients are generally important for regulating phytoplankton layering, observations of the vertical distribution of phytoplankton are sometimes difficult to interpret in deep stratified systems that support a nutrient gradient. Bormans et al. (1999) claim that changes in algal buoyancy appear to be mainly lightdependent and not nutrient-dependent. In strongly stratified systems with a nutrient-depleted epilimnion, the deepening of the surface mixed layer because of daily processes or intermittent stormy events can provide a pumping mechanism for re-supplying nutrients to the 
July survey

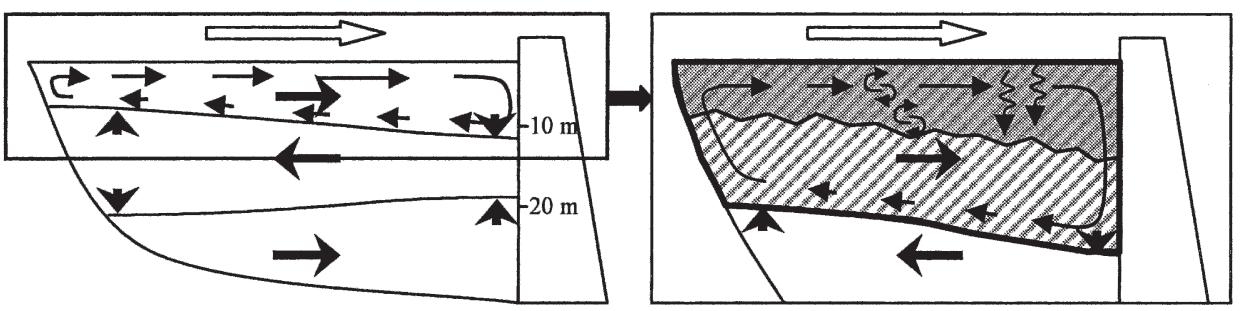

September survey

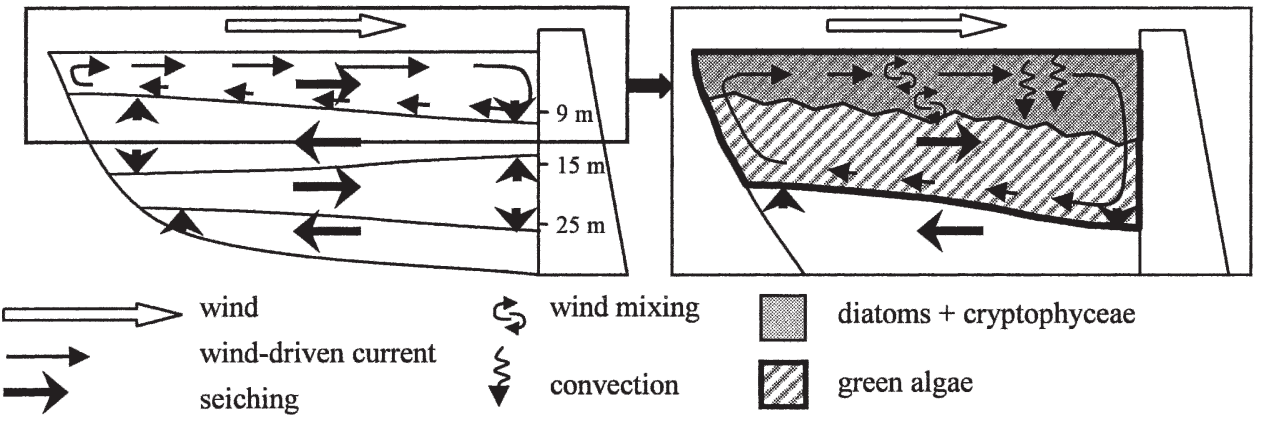

Fig. 10. Schematic diagram of the seiching, the wind-driven current, the mixing caused by wind and the surface cooling for both (a) July and (b) September surveys. The extension of green algae, diatoms, and cryptophyceae is also indicated in the enlarged diagrams located in the right panels of each figure.

epilimnion (Gardner et al. 1999; Bormans et al. 2004). Our results show that in the Sau reservoir horizontal and vertical currents will dominate over growth and will give the most significant variations in phytoplankton concentration in the water column.

The present data set from Sau reservoir demonstrates the effect of vertical and horizontal movements in the phytoplankton distribution in the water column. Mixing caused by surface cooling causes the surface layer to deepen and a mixed distribution of phytoplankton to form at the surface. Mixing caused by surface cooling generally dominates at night, whereas during the day there are only weak mixing and low turbulence levels because of the weak winds that prevail in this time. Because of this fact, layering is possible mainly during the day. In contrast, these layers quickly disappear when water parcels mix because of a medium external forcing (convection) leading from low to moderate turbulence levels. During the day phytoplankton populations become shallower because of the rise of isotherms caused by both solar heating and internal waves. Therefore, organisms that do not sink or swim will move passively because of all of the above mentioned processes.

Horizontal advection caused by the wind-driven current at the surface of the water column also plays an important role in the transport of phytoplankton. This indicates that the phytoplankton is distributed in patches along the reservoir, probably because of horizontal differences in habitat conditions. Diatoms and cryptophyceae seem to be heterogeneously distributed, whereas the horizontal distribution of green algae seems to be more homogenous. More work should be done to investigate the reason for the different distributions of these communities throughout the reservoir. In addition, the wind excites internal waves or seiches in the reservoir. Seiches and the wind-driven current, together with solar heating and the abovementioned convection, determine phytoplankton distribution in the water column in the reservoir from the surface down to deeper layers. To a lesser degree, community migrations to accommodate cells to their preferred light requirements can also be dominant when both convection and advection of water parcels stop.

All of these results demonstrate that the phytoplankton dynamics depend on several external factors, and to understand their behavior it is necessary to determine all of the external variables, such as the heat balance, wind velocity, and the presence of internal wave oscillations. This study also shows that, since each phytoplankton group selects its preferred position in the water column, the dynamics of each group depend on the physics of the region where the phytoplankton is located. With this work we also demonstrate the importance of considering both high temporal and spatial measurements to describe the phytoplankton dynamics completely.

\section{References}

Alldredge, A. L., AND others. 2002. Occurrence and mechanics of formation of a dramatic thin layer of marine snow in a shallow Pacific fjord. Mar Ecol Progr. 233: 1-12.

Armengol, J., AND others. 1999. Longitudinal processes in canyon type reservoirs: The case of Sau (N.E. Spain). In J. G. Tundisi, and M. Straskraba [eds.], Theoretical reservoir ecology and its applications. Backhuys Publishers.

Baker, P. D., J. D. Brookes, M. D. Burch, H. R. Mainer, And G. G. GANF. 2000. Advection, growth and nutrient status of phytoplankton populations in the lower river Murray, South 
Australia. Regulated Rivers: Research \& Management. 16: 327-344.

Beutler, M., And others. 2002. A fluorometric method for the differentiation of algal populations in vivo and in situ. Photosynth Res. 72: 39-53.

Bjornsen, P. K., and T. K. Nielsen. 1991. Decimeter scale heterogeneity in the plankton during a pycnocline bloom of Gyrodinium aureolum. Mar Ecol Progr. 73: 263-267.

Bormans, B., AND S. A. CondiE. 1998. Modelling the distribution of Anabaena and Melosira in a stratified river weir pool. Hydrobiologia 364: 3-13.

Bormans, M., P. W. Ford, L. Fabbro, and G. Hancock. 2004. Onset and persistence of cyanobacterial blooms in a large impounded tropical river, Australia. Mar Freshwat Res. 55: $1-15$.

—, B. S. Sherman, And I. T. Webster. 1999. Is buoyancy regulation in cyanobacteria and adaptation to exploit separation on light and nutrients? Mar Freshwat Res. 50: 897-906.

Brainerd, K. E., AND M. C. GregG. 1993. Diurnal restratification and turbulence in the oceanic surface mixed layer 1. Observations. J Geophys Res. 98: 22645-22656.

Brutsaert, W. H. 1982. Evaporation into the atmosphere: Theory, history, and applications. D. Reidel.

Cloern, J. E. 1991. Tidal stirring and phytoplankton bloom dynamics in an estuary. J Mar Res. 49: 203-221.

Colomer, J., E. Roget, And X. Casamitjana. 1996. Daytime heat balance for estimating non-radiative fluxes of lake Banyoles, Spain. Hydrolog Process. 10: 721-726.

Deardoff, J. W. 1970. Convective velocity and temperature scales for unstable planetary boundary layer and for Rayleigh convection. J Atmos Sci. 27: 1211-1213.

Dekshenieks, M. M., P. L. Donaghay, J. M. Sullivan, J. E. B. Rines, T. R. Osborn, And M. S. Twardowski. 2001. Temporal and spatial occurrence of thin phytoplankton layers in relation to physical processes. Mar Ecol Progr. 223: $61-71$.

Dickman, M., K. Stewart, and M. Servantvildary. 1993. Spatial heterogeneity of summer phytoplankton and water chemistry in a large volcanic spring-fed lake in northern Iceland. Arctic Alpine Res. 25: 228-239,

EinARsson, Á., AND others. 2004. The ecology of Lake Myvatn and the River Laxá: Variation in space and time. Aquat Ecol. 38: $317-348$.

Elliott, J. A., A. E. Irish, And C. S. Reynolds. 2001. The effects of vertical mixing on a phytoplankton community: A modeling approach to the intermediate disturbance hypothesis. Freshwat Biol. 46: 1291-1297.

Fischer, H. B., E. J. List, R. C. Y. Koh, J. Imberger, And N. H. Brooks. 1979. Mixing in inland and coastal waters. Academic Press.

Gardner, W. D., J. S. Gundersen, M. J. Richardson, and I. D. WALSH. 1999. The role of seasonal and diel changes in mixedlayer depth on carbon and chlorophyll distributions in the Arabian Sea. Deep-Sea Res II. 46: 1833-1858.

Gentien, P., M. Luven, M. Lehaitre, and J. L. Duvent. 1995. Insitu depth profiling of particle sizes. Deep-Sea Res. 42: $1297-1312$.

Gregor, J., And B. Marsalek. 2004. Freshwater phytoplankton quantification by chlorophyll $\alpha$ : A comparative study of in vitro, in vivo and in situ methods. Water Res. 38: 517-522.

- R. Geris, B. Marsalek, J. Hetesa, and P. Marvan. 2005. In situ quantification of phytoplankton in reservoirs using a submersible spectrofluorometer. Hydrobiologia 548: $141-151$.
Harris, G. P., And A. M. Trimbee. 1986. Phytoplankton population dynamics of a small reservoir: Physical biological coupling and the time scales of community change. J Plankton Res. 8: 1011-1025.

Hedger, R. D., N. R. B. Olsen, D. G. George, T. J. Malthus, AND P. M. AtKinson. 2004. Modelling spatial distributions of Ceratium hirundinella and Microcystis spp. in a small productive British lake. Hydrobiologia 528: 217-227.

Ibelings, B. W., L. R. Mur, And A. E. Walsby. 1991. Diurnal changes in buoyancy and vertical distribution in populations of Microcystis in 2 shallow lakes. J Plankton Res. 13: 419-436.

Imberger, J. 1985. The diurnal mixed layer. Limnol. Oceanogr. 30: $737-770$.

. 1994. Transport processes in lakes: A review, p. 99-193. In R. Margalef [ed.], Limnology now: A paradigm of planetary problems. Elsevier.

Jacquet, S., J. F. Lennon, D. Marie, and D. Vaulot. 1998. Picoplankton population dynamics in coastal waters of the northwestern Mediterranean Sea. Limnol. Oceanogr. 43: 1916-1931.

KIM, J. W. 1976. Generalized bulk model of the oceanic mixed layer. J Phys Oceanogr. 6: 686-695.

Kimball, B. A., S. B. Idso, and J. K. Aase. 1982. A model of thermal radiation from partly cloudy and overcast skies. Water Resour Res. 18: 931-936.

Leboulanger, C., U. Dorigo, S. Jacquet, B. Le Berre, G. Paolini, And J.-F. Humbert. 2002. Application of a submersible spectrofluorometer for rapid monitoring of freshwater cyanobacterial blooms: A case study. Aquat Microb Ecol. 30: $83-89$.

Lewis, D. M., J. A. Elliot, M. F. Lambert, and C. S. Reynolds. 2002. The simulation of an Australian reservoir using a phytoplankton community model. PROTECH. Ecol Model. 150: $107-116$. , J. D. Brookes, A. E. Irish, M. F. Lambert, and C. S. Reynolds. 2003. Modelling the effects of artificial mixing and copper sulphate dosing on phytoplankton in an Australian reservoir. Lakes \& Reservoirs: Research and Management. 8: 31-40.

MacIntyre, S. 1998. Turbulent mixing and resource supply to phytoplankton. In J. Imberger [ed.], Physical processes in lakes and oceans. Coastal and estuarine studies 54. American Geophysical Union.

, K. M. Flynn, R. Jellison, and J. R. Romero. 1999. Boundary mixing and nutrient fluxes in Mono Lake, California. Limnol. Oceanogr. 44: 512-529.

$\longrightarrow$, AND J. M. Melack. 1995. Vertical and horizontal transport in lakes: Linking littoral, benthic and pelagic habitats. Journal of the North American Benthological Society. 14: 599-615.

—, J. R. Romero, And G. W. KLING. 2002. Spatial-temporal variability in surface layer deepening and lateral advection in an embayment of Lake Victoria, East Africa. Limnol. Oceanogr. 47: 656-671.

McManus, M. A., O. M. Cheriton, P. J. Drake, D. V. Holliday, C. D. Storlazzi, P. L. Donaghay, and C. F. Greenlaw. 2005. Effects of physical processes on structure and transport of thin zooplankton layers in the coastal ocean. Mar Ecol Progr. 301: 199-215.

, AND OTHERs. 2003. Characteristics, distribution and persistence of thin layers over a 48 hour period. Mar Ecol Progr. 261: 1-19.

O'Brien, K. R., G. N. Ivey, D. P. Hamilton, A. M. Waite, and P. M. Visser. 2003. Simple mixing criteria for the growth of 
negatively buoyant phytoplankton. Limnol. Oceanogr. 48: $1326-1337$.

REYNOLDS, C. S. 1984. Phytoplankton periodicity-interactions of form, function and environmental variability. Freshwat Biol. 14: $111-142$.

1990. Temporal scales of variability in pelagic environments and the response of phytoplankton. Freshwat Biol. 23: $25-53$.

Rojo, C., and M. Alvarez-Cobelas. 2001. Phytoplankton structure and dynamics at a daily temporal scale: Response to the thermal overturn. Archiv für Hydrobiologie. 151: 549-569.
Serra, T., T. C. Granata, J. Colomer, A. Stips, F. Møhlenberg, and X. Casamituana. 2003. The role of advection and turbulent mixing in the vertical distribution of phytoplankton. Estuar Coast Shelf Sci. 56: 53-62.

Vidal, J., X. Casamitjana, J. Colomer, and T. Serra. 2005. The internal wave field in Sau reservoir: Observation and modeling of a third vertical mode. Limnol. Oceanogr. 50: $1326-1333$.

Received: 08 November 2005 Accepted: 16 July 2006 Amended: 04 October 2006 